\title{
Pengaruh Informasi Asimetri dan Voluntary Disclosure terhadap Cost of Capital pada Perusahaan Manufaktur yang Terdaftar di Bursa Efek Indonesia
}

\author{
Indayani \\ Dewi Mutia \\ Fakultas Ekonomi Universitas Syiah Kuala \\ Jalan Teuku Nyak Arief, Darussalam 23111 \\ Email: inya74@gmail.com
}

\begin{abstract}
The aim of this research is to examine the influence of asymmetry information and voluntary disclosure, both simultaneously and partially, toward cost of capital on listed companies from the manufacturing sector at the Indonesia Stock Exchange (BEI) for the year 2007-2010. By using census method and balanced panel data, there are 26 of the population total from companies of manufacturing sector fulfill the population criteria during 4 years of the observation. The results show that (1) asymmetry information and voluntary disclosure simultaneously have influence toward the cost of capital on listed companies from the manufacturing sector at the Indonesia Stock Exchange (2) asymmetry information has influence toward the cost of capital on listed companies from the manufacturing sector at the Indonesia Stock Exchange (3) voluntary disclosure has influence toward the cost of capital on listed companies from the manufacturing sector at the Indonesia Stock Exchange.
\end{abstract}

Keywords: Cost of capital, asymmetry information, and voluntary disclosure

\section{PENDAHULUAN}

Pada laporan keuangan, modal perusahaan dicatat di sisi pasiva yang menunjukkan sumber dana perusahaan (Atmaja, 2008: 301). Dalam melakukan pemenuhan dana, perusahaan dapat memperoleh dana tersebut dari dalam perusahaan (modal sendiri) dan dari luar perusahaan (modal asing) (Mayangsari, 2001). Dilihat dari perekonomian Indonesia saat ini, fenomena yang terjadi adalah semakin tingginya biaya modal pada suatu perusahaan maka dampaknya cukup besar untuk investasi, di mana sedikitnya perusahaan yang melakukan penawaran umum saham, dan rendahnya aktivitas perusahaan untuk mencari dana. Secara umum, keputusan investasi sangat tergantung pada kemampuan investasi tersebut untuk memenuhi cost of capital yang ditanggung dari dana yang diinvestasikan tersebut (Bramantyo, 2008).

Cost of capital ini berkaitan dengan risiko investasi saham perusahaan. Perusahaan dapat memperoleh modal ekuitas dengan dua cara yaitu, dengan laba ditahan dan mengeluarkan saham baru. Manajemen tidak boleh menginvestasikan uang pemegang saham jika mereka tidak dapat menghasilkan tingkat pengembalian yang sekurangnya sama dengan apa yang diperoleh pemegang saham apabila melakukan investasi di tempat yang lain dengan resiko yang sama (Djakman, 2000). Cost of capital salah satunya dipengaruhi oleh informasi asimetri yang mem-

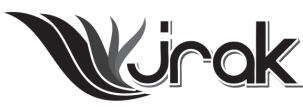

Jurnal Reviu Akuntansi dan Keuangan ISSN: 2088-0685 Vol.3 No. 1, April 2013 Pp 373-382 bahas masalah keagenan. 
Pengaruh

Informasi

Asimetri...

374
Komalasari (2000) menyebutkan bahwa teori keagenan (agency theory) mengimplikasikan adanya informasi asimetri antara manajer sebagai agen dan pemilik (dalam hal ini adalah pemegang saham) sebagai prinsipal. Informasi asimetri muncul ketika manajer lebih mengetahui informasi internal dan prospek perusahaan di masa yang akan datang di bandingkan pemegang saham dan stakeholder Iainnya. Ketika terdapat informasi asimetri, manajer dapat memberikan sinyal mengenai kondisi perusahan kepada investor guna memaksimalisasi biaya.

Selain itu, disebutkan pula aktivitas yang dilakukan oleh investor di pasar modal ditentukan oleh informasi yang mereka perol eh baik secara langsung (laporan publik) maupun tidak langsung (insider trading). Oleh karena pelaku pasar modal mempunyai kemampuan yang terbatas terhadap persepsi masa yang akan datang, maka adanya informasi asimetri menimbulkan masalah adserveselection (informasi asimetri) yang mendorong dealer untuk menutupi kerugian dari pedagang terinformasi dengan meningkatkan spread-nya terhadap pedagang likuid. J adi, dapat dikatakan bahwa informasi asimetri yang terjadi antara dealer dan pedagang terinformasi tercermin pada spread yang ditentukannya.

Informasi yang diungkapkan oleh pihak manajemen atau perusahaan merupakan salah satu faktor yang mempengaruhi cost of capital, yaitu tingkat vol untary discl osure atau pengungkapan sukarela. Perusahaan yang tidak memberikan tingkat discl osure yang memadai ol eh sebagian investor dipandang sebagai laporan keuangan yang berisiko (Gulo, 2000). Disclosure yang memadai diberikan oleh perusahaan karena mempunyai kepentingan yaitu adanya harapan mengenai dampak yang positif dari disclosure yang disampaikan.

Meskipun tinjauan secara teoritis dan analistis mengenai keterkaitan antara pengungkapan, cost of capital cukup signifikan, namun tampaknya sedikit sekali penelitian empiris yang mendukung hal ini. Ketidakkonsistensian pada hasil penelitian terdahulu semakin menambah perdebatan diantara para praktisi mengenai manfaat dari semakin luasnya pengungkapan, sehingga penelitian untuk mengetahui hubungan antara tingkat ungkapan dan asimetri informasi terhadap cost of capital merupakan hal yang penting untuk dilakukan.

Penelitian guna menguji pengaruh pengungkapan terhadap cost of capital yang dilakukan oleh Khomsiyah dan Susanti (2003) menunjukkan bahwa tidak ada hubungan antara pengungkapan dan bid-ask spread pada tanggal-tanggal pengamatan tujuh hari sebelum tanggal pelaporan keuangan, tujuh hari setelah pelaporan keuangan, maupun pada tanggal pelaporan keuangan. Murni (2002) meneliti hubungan antara luas ungkapan sukarela, asimetri informasi, dan cost of equity capital. Dalam penghitungan cost of equity capital digunakan pendekatan CAPM (Capital Asset Pricing Market). Hasilnya menunjukkan bahwa pengungkapan sukarela yang dibuat oleh manajemen dalam laporan tahunan perusahaan tidak menurunkan cost of equity capital perusahaan. Hal ini juga konsisten dengan penelitian Elliot dan J acobson (1994) yang menemukan bahwa manfaat ungkapan informasi secara sukarela adalah semakin kecilnya cost of capital (biaya modal).

Berdasarkan ketidakkonsistenan antara satu hasil penelitian dengan penelitian lainnya, maka penelitian ini difokuskan untuk mereplikasi penelitian sebelumnya yang dilakukan oleh Mardiyah (2002) mengenai pengaruh informasi asimetri dan disclosure terhadap cost of capital. Namun, terdapat per ebedaan dengan penelitian sebelumnya yaitu pada objek dan tahun penelitian. Mardiyah (2002) meneliti pengaruh informasi asimetri dan discl oureterhadap cost of capital pada sel uruh perusahaan publik yang terdaftar di Bursa Efek J akarta pada tahun 1996. Sedangkan penelitian ini memfokuskan objek penelitian pada perusahaan manufaktur yang terdaftar di Bursa Efek Indonesia periode 2007-2010. Alasan memilih perusahaan manufaktur sebagai objek penelitian ini adalah karena penelitian sebelumnya menggunakan perusahaan publik. Selain itu alasan lainnya adalah karena saham perusahaan manufaktur lebih banyak diminati ol eh investor daripada perusahaan lainnya. Perusahaan manufaktur tidak terikat pada per- 
aturan pemerintah, serta perusahaan manufaktur merupakan salah satu aset yang memiliki peranan penting dalam pembangunan. Terlebih lagi dalam menghadapi era persaingan bebas, perusahaan manufaktur dituntut semakin efektif dalam mempublikasikan Iaporan keuangannya dimana pengguna laporan keuangan memiliki kepentingan dalam hal tersebut.

Pertanyaan yang diajukan dalam penelitian ini adalah: Apakah informasi asimetri dan vol untary discl osure, baik secara bersama-sama maupun secara parsial berpengaruh terhadap cost of capital pada perusahaan manufaktur yang terdaftar di Bursa Efek Indonesia?

\section{PENGEMBANGAN HIPOTESIS}

\section{a. Pengaruh Informasi Asimetri terhadap Cost of Capital}

Informasi akuntansi yang berkualitas berguna bagi investor untuk menurunkan asimetri informasi. Asimetri informasi timbul ketika manajer lebih mengetahui informasi internal dan prospek perusahaan di masa depan dibandingkan stakehol der lainnya. Ketika timbul asimetri informasi, keputusan pengungkapan yang dibuat oleh manajer dapat mempengaruhi harga saham sebab asimetri informasi antara investor yang lebih terinformasi dengan investor yang kurang terinformasi menimbulkan biaya transaksi dan mengurangi likuiditas yang diharapkan dalam pasar untuk saham-saham perusahaan.

Diamond dan Verrecchia (1991) menguraikan bahwa jika harga sekuritas pada tanggal t lebih tinggi (cost of capital-nya lebih rendah) karena adanya pengungkapan informasi private maka pasar akan menjadi lebih likuid pada tanggal $t+1$. $\mathrm{Hal}$ ini menyebabkan pedagang besar mengambil posisi yang lebih besar pada tanggal t dengan harga tertentu. Peningkatan permintaan ini menyebabkan harga saham meningkat pada tanggal $t$, sehingga cost of capital-nya menurun.

Komalasari (2000) meneliti hubungan antara asimetri informasi dan cost of capital, dimana asimetri informasi diukur dengan menggunakan bid-ask spread. Hasil menunjukkan bahwa ada hubungan positif antara asimetri informasi dengan cost of capital. Dari beberapa penelitian terdahulu, asimetri informasi sering diproksikan dengan bid-ask spread.

\section{b. Pengaruh Voluntary Disclosure terhadap Cost of Capital}

Riset empiris mengenai pengungkapan sukarela (voluntary disclosure) dan cost of capital sangat terbatas. Botosan (1997) meneliti dampak tingkat pengungkapan terhadap cost of capital. I a menguji asosiasi tingkat pengungkapan dan cost of capital dengan meregresi estimasi cost of capital atas beta pasar, ukuran perusahaan dan ukuran tingkat pengungkapan. Hasil penelitian menunjukkan bahwa untuk perusahan yang diikuti oleh sebagian kecil analis, semakin besar tingkat pengungkapannya akan diasosiasikan dengan cost of capital yang lebih rendah, sedangkan untuk perusahaan yang diikuti oleh sebagian besar analis menunjukkan tidak terdapat asosiasi antara tingkat pengungkapan dengan cost of capital. Lebih jauh dinyatakan bahwa hasil yang terakhir kemungkinan disebabkan karena ukuran pengungkapan yang digunakan terbatas pada laporan tahunan, sehingga tidak memberikan proksi yang cukup kuat untuk keseluruhan tingkat pengungkapan. J enkins Committee dalam Gulo (2000), menyatakan bahwa manfaat penting dari perluasan pengungkapan adalah semakin turunnya cost of capital. Akan tetapi pernyataan tersebut disanggah oleh Financial Excecutives Institute, dengan alasan bahwa perluasan pengungkapan yang di sebutkan dalam laporan Committee tersebut adalah ditujukan kepada traders saham yang ingin menambahkan volatilitas (volatility) harga saham, sehingga meningkatkan resiko dan membawa kepada cost of capital yang tinggi. 
Pengaruh Informasi Asimetri...

\section{6}

Gambar 1 .

Skema Kerangka

Pemikiran
Berdasarkan kerangka Penelitian yang telah dikemukakan sebelumnya, maka hipotesis yang dibentuk adalah:

H 1: I nformasi asimetri dan voluntary disclosure baik secara bersama-sama maupun secara parsial berpengaruh terhadap cost of capital pada perusahaan manufaktur di Bursa Efek Indonesia.METODE PENELITIAN

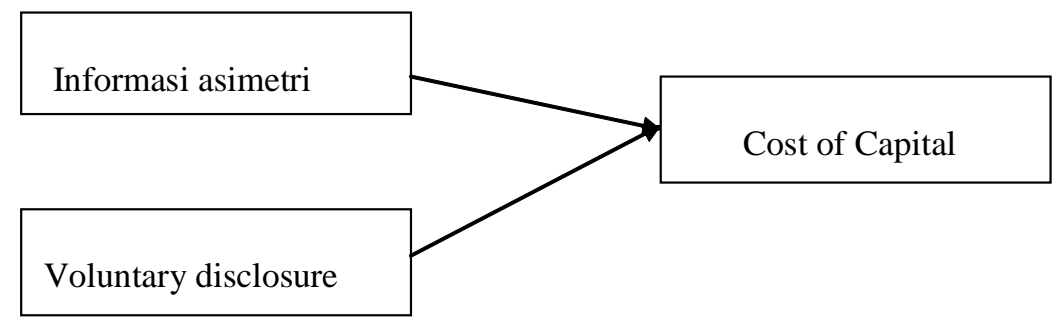

\section{Desain Penelitian}

Desain atau rancangan penelitian dalam penelitian ini meliputi tujuan penelitian yang bertujuan menguji pengaruh variabel independen (informasi asimetri dan voluntary disclosure) terhadap variabel dependen (cost of capital) melalui pengujian hipotesis. Sesuai dengan tujuan penelitian, maka jenis investigasinya bersifat korelasional yaitu peneliti mengidentifikasikan faktor-faktor penting yang berkaitan dengan masalah penelitian diantaranya informasi asimetri dan vol untary disclosure. Tingkat intervensi peneliti sedang karena peneliti tidak memanipulasi variabel yang akan diteliti dan hanya menentukan beberapa faktor masalah yang akan diteliti.

Situasi penelitian korelasional ini dilakukan dalamsituasi yang tidak diatur, berproses secara normal dan alami dengan menggunakan eksperimen lapangan terhadap perusahaan yang menjadi objek penelitian atau dikenal dengan istilah unit analisis.Yang menjadi unit analisis pada penelitian ini yaitu perusahaan manufaktur yang terdaftar di Bursa Efek Indonesia. Horizon waktu yang digunakan adalah gabungan cross sectional dan Iongitudinal yang disebut pool ed data/panel data dengan mengumpulkan data per tahun selama 4 tahun berturut-turut yaitu tahun 2007-2010 di BEI.

\section{Populasi Penelitian}

Pada penelitian ini yang menjadi populasi penelitian adalah perusahaan manufaktur yang terdaftar di Bursa Efek Indonesia untuk periode tahun 20072010. Pemilihan populasi adalah metode sensus. Sensus berarti meneliti seluruh elemen populasi (Indriantoro dan Supomo, 2002: 115). Adapun perusahaan manufaktur yang menjadi populasi sasaran dalam penelitian ini adalah perusahaan mnufaktur yang mempunyai kriteria sebagai berikut:

1. Perusahaan yang memiliki laba positif.

2. Perusahaan tidak menghentikan aktivitasnya di pasar bursa, tidak menghentikan operasinya dan tidak melakukan penggabungan usaha dan tidak ber ubah status sektor industrinya.

3. Menerbitkan data laporan tahunan (annual report).

Berdasarkan tahun pengamatan yang digunakan dalam penelitian ini yaitu sel ama 4 tahun berturut-turut dari tahun 2007-2010 maka jumlah observasi dal am penelitian ini sebanyak 4 tahun observasi $\times 26$ populasi sasaran $=104$ observasi.

\section{Sumber dan Teknik Pengumpulan Data}

Data yang digunakan dalam penelitian ini adalah data sekunder. Dalam penelitian ini data yang digunakan adalah pooled data/panel data (pooling of time 
series and cross sectional observation). Pada penelitian ini panel data yang dimaksud adalah balanced panel data yaitu perusahaan yang sama dalam beberapa waktu yang diambil sebagai subjek pengamatan. Penelitian ini hanya menggunakan data sekunder yang berupa:

1. Data laporan keuangan publikasi tahunan (annual report) untuk periode tahun 2007 sampai dengan 2010.

2. Laba tahunan yang diperoleh dari data monitoring laporan keuangan yang dikeluarkan oleh BAPEPAM dan harian Bisnis Indonesia.

3. Data transaksi harian berupa return, volume perdagangan, harga saham, harga penawaran, harga permintaan, volume permintaan, volume penawaran, beta, IHSG, dan return bebas resiko. Data ini diambil pada Indonesian Capital Market Direktory (ICMD), yang diperol eh dari Pusat Referensi Pasar Modal (PRPM).

\section{Variabel Dependen}

Variabel dependen dalam penelitian ini adalah cost of capital perusahaan. Cost of capital adalah jumlah biaya yang dikeluarkan oleh perusahaan untuk menyediakan informasi bagi publik (pemegang saham, investor, pemerintah, kreditur, dan masyarakat secara umum) (Tarjo, 2005). Skala yang digunakan adalah skala rasio. Perhitungan cost of capital setiap perusahaan sampel dengan menggunakan model COC (Cost of Capital) dengan pendekatan Capital Asset Pricing Model (CAPM), yaitu:

$$
\mathrm{COC}=\mathrm{Rft}+\beta \mathrm{i}(\mathrm{Rmt}-\mathrm{Rft})
$$

Rft = Return bebas risiko yang diproksikan dengan tingkat suku bunga SertifikatBank I ndonesia.

Rmt = Return pasar yang di peroleh dari I ndeks Harga Saham Gabungan (IHSG) pada hari t ditambah I HSG pada hari t-1 dibagi dengan IHSG pada hari t-1.

$\beta \mathrm{i} \quad=$ Risikotidak sistematis untuk setiap saham perusahaan $\mathrm{i}$.

Beta adalah pengukur risiko sistematik dari suatu sekuritas atau portofolio relatif terhadap risiko pasar. Beta dapat dihitung dengan rumus (J ogiyanto, 2007:323):

$$
\beta i=\frac{\sum_{t=1}^{\mathrm{n}} \text { (Rit-Rit). ( Rmt- Rmt) }}{\sum_{\mathrm{t}=1(\mathrm{Rmt}-\mathrm{Rmt})}^{\mathrm{n}}}
$$

$\beta \mathrm{i}=$ Beta (risiko)

Rit $=$ Return bulanan saham individual

Rit $=$ Return rata-rata saham individual

Rmt $=$ Return pasar bulanan

Rmt $=$ Return pasar rata-rata dalam satu periode

Untuk mencari Return Saham (Rit) maka digunakan rumus sebagai berikut:

$$
\text { Rit }=\frac{\text { Pit }- \text { Pit }-1}{\text { Pit-1 }}
$$


$\begin{array}{ll}\text { Pengaruh } & \text { Dimana: } \\ \text { Informasi } & \text { Pit }=\text { Harga saham periode ini } \\ \text { Asimetri... } & \text { Pit-1 }=\text { Harga saham periode sebel umnya }\end{array}$

Untuk mencari Return Market (Rmt) maka digunakan rumus sebagai berikut:

$$
\mathrm{Rmt}=\frac{\mathrm{IHSGt}-\mathrm{IHSGt}-1}{\mathrm{IHSGt}}
$$

IHSGt = Nilai IHSG periode ini

IHSG = Nilai IHSG periode sebelumnya

\section{Variabel Independen}

a. Informasi Asimetri

Informasi asimetri diproksikan dengan bid-ask-spread. Bid-ask spread adalah selisih harga beli tertinggi dengan harga jual terendah (harga terbaik) yang dilakukan trader. Rumusan untuk menghitung bid-ask-spread berdasarkan penelitian Halim dan Hidayat (2000) adalah sebagai berikut:

$$
\text { RBAt }=\frac{(\mathrm{Hat}-\mathrm{HBt}) .100 \%}{1 / 2(\mathrm{HAt}+\mathrm{HBt})}
$$

RBA $_{t}=$ Bid-ask-spread pada hari ket

$\mathrm{HA}_{\mathrm{t}}=\mathrm{Harga}$ penawaran penjualan pada hari ket

$\mathrm{HB}_{\mathrm{t}}=\mathrm{Harga}$ penawaran pembelian pada hari ket

$\mathrm{t}=\mathrm{H}$ arga penawaran penjualan dan pembelian pada 5 hari setelah pengumuman Iaporan keuangan.

b. Voluntary Discosure

Voluntary disclosure atau pengungkapan sukarela merupakan pengungkapan butir-butir yang dilakukan secara sukarela oleh perusahaan tanpa diharuskan oleh peraturan yang berlaku (Mardiyah, 2002). Untuk mengukur kelengkapan pengungkapan dapat dinyatakan dalam bentuk indeks kelengkapan pengungkapan. I ndeks pengungkapan untuk setiap perusahaan sampel diperoleh dengan cara berikut (Almilia dan Retrinasari, 2007):

1. Memberi skor untuk setiap item pengungkapan secara dikotomi, dimana jika suatu item diungkapkan diberi nilai satu dan jika tidak diungkapkan akan diberi nilai nol.

2. Skor yang diperol eh setiap perusahaan dijumlahkan untuk mendapatkan skor total.

3. Menghitung indeks kelengkapan dengan cara membagi total skor yang diperoleh dengan total skor yang diharapkan dapat diperoleh oleh perusahaan.

Variabel ini dapat diukur dengan Disclosure Index yaitu indeks Wallace dengan rumusan sebagai berikut (Hertanti, 2005):

$$
\mathrm{DI}=\frac{\mathrm{n}}{\mathrm{K}} \times 100 \%
$$


DI = Disclosurelndex

$\mathrm{n} \quad=\mathrm{J}$ umlah item yang diungkapkan oleh perusahaan

$\mathrm{k}=\mathrm{J}$ umlah item yang seharusnya diungkapkan

\section{Teknik Analisis Data}

Analisa data dilakukan dengan menggunakan metode regresi linier berganda (multiple regression analysis) yang menghubungkan antara variabel dependen dengan variabel independen. Analisis ini bertujuan untuk menguji pengaruh informasi asimetri dan voluntary disclosureterhadap cost of capital pada perusahaan manufaktur yang terdaftar di Bursa Efek Indonesia Persamaan regresi yang digunakan dalam penelitian ini adalah sebagai berikut:

$$
\mathrm{Y}=\alpha+\beta 1 \mathrm{X} 1+\beta 2 \times 2+\mathrm{e}
$$

$Y \quad=$ Cost of Capital

$\alpha \quad=$ Konstanta

$\beta_{1} \beta_{2}=$ Koefisien Regresi

$\mathrm{X}_{1}=$ Informasi Asimetri

$\mathrm{X}_{2}$ =Voluntary Disclosure

$\varepsilon \quad=$ Eror

\section{Rancangan Pengujian Hipotesis}

Untuk menentukan menerima atau menolak hi potesis yang diajukan, maka perlu dilakukan pengujian secara statistic yang diolah dengan program komputer Standard Package for Social Science (SPSS)17.0 for Windows Evolution Version. Sebelum pengujian hipotesis, terlebih dahulu disusun rancangan pengujian hipotesis.

Untuk menguji pengaruh informasi asimetri $\left(X_{1}\right)$ dan voluntary disclosure $\left(\mathrm{X}_{2}\right)$ terhadap cost of capital $(\mathrm{Y})$ dilakukan dengan cara meregres semua variabel dalam penelitian baik variabel dependen maupun variabel independen. Penelitian ini menggunakan metodesensus, dengan demikian tidak dilakukan uji signifikansi, baik uji-f untuk pengaruh secara bersama-sama maupun uji-t untuk pengaruh secara parsial. Kesimpulan diambil langsung dari nilai koefisien regresi masingmasing variabel.

Untuk menguji hipotesis pertama $\left(\mathrm{H}_{1}\right)$ apakah secara simultan variabel independen $\left(X_{i}: i=1,2\right)$ berpengaruh terhadap variabel dependen $(Y)$, digunakan uji simultan dengan langkah sebagai berikut:

1. Menentukan hipotesis nol $\left(\mathrm{H}_{0}\right)$ dan hipotesis alternatif $\left(\mathrm{H}_{\mathrm{A}}\right)$

$H_{01}: \beta_{1}=\beta_{2}=0$; informasi asimetri dan voluntary discl osure secara bersamasama tidak berpengaruh terhadap cost of capital pada perusahaan manufaktur yang ter daftar di Bursa E fek Indonesia.

$\mathrm{Ha1}$ : Paling sedikit ada satu $\beta_{\mathrm{i}} \neq 0, \mathrm{i}=1,2$; informasi asimetri dan voluntary discl osure secara bersama-sama berpengaruh terhadap cost of capital pada perusahaan manufaktur yang terdaftar di Bursa Efek Indonesia.

2. Menentukan kriteria penerimaan dan penolakan hipotesis.

Kriteria penerimaan dan penolakan hipotesis adalah sebagai berikut:

J ika $\beta_{\mathrm{i}}(\mathrm{i}=1,2)=0$ : $\mathrm{H}_{0}$ diterima $\left(\mathrm{H}_{\mathrm{a}}\right.$ ditolak)

J ika paling sedikit ada satu $\beta_{\mathrm{i}}(\mathrm{i}=1,2)^{1} 0$ : $\mathrm{H}_{0} \operatorname{ditolak}\left(\mathrm{H}_{\mathrm{a}}\right.$ diterima $)$

$\mathrm{H}_{0}$ diterima $\left(\mathrm{H}_{\mathrm{a}}\right.$ ditolak) artinya variabel independen secara bersama-sama tidak berpengaruh terhadap variabel dependen, sedangkan $\mathrm{H}_{0}$ ditolak (Ha diterima) artinya bahwa variabel independen secara bersama-sama berpengaruh terhadap variabel dependen. 
Pengaruh Informasi Asimetri...

380

Tabel 1.

Output regresi
Selanjutnya untuk mengetahui apakah variabel independen $(X)$ secara parsial berpengaruh terhadap variabel dependen $(\mathrm{Y})$ digunakan uji parsial, dengan langkahlangkahnya sebagai berikut:

$\mathrm{H}_{02:} \beta_{1}=0$; I nformasi asimetri tidak berpengaruh terhadap cost of capital pada perusahaan manufaktur yang terdaftar di Bursa E fek Indonesia.

$\mathrm{Ha2}:{ }^{\beta} 1 \neq 0$; Informasi asimetri berpengaruh terhadap cost of capital pada perusahaan manufaktur yang terdaftar di Bursa E fek Indonesia.

$\mathrm{H}_{03} \beta_{2}=0$; Vol untary discl osuretidak berpengaruh terhadap cost of capital pada perusahaan manufaktur yang terdaftar di Bursa Efek Indonesia.

Ha3: $\beta_{2} \neq 0$; Voluntary disclosure berpengaruh terhadap cost of capital pada perusahaan manufaktur yang terdaftar di Bursa E fek I ndonesia.

Kriteria penerimaan dan penolakan hipotesis adalah sebagai berikut:

1. J ika $\beta_{1}=0: \mathrm{H}_{02}$ diterima $\left(\mathrm{H}_{\mathrm{a} 2}\right.$ ditolak); J ika $\beta_{1} \neq 0: \mathrm{H}_{02}$ ditolak $\left(\mathrm{H}_{\mathrm{a} 2}\right.$ diterima). $\mathrm{H}_{02}$ diterima $\left(\mathrm{H}_{\mathrm{a} 2}\right.$ ditolak) artinya informasi asimetri secara parsial tidak berpengaruh terhadap cost of capital, sedangkan $\mathrm{H}_{02}$ ditolak $\left(\mathrm{H}_{\mathrm{a} 2}\right.$ diterima) artinya informasi asimetri secara parsial berpengaruh terhadap cost of capital.

2. J ika $\beta_{2}=0: \mathrm{H}_{03}$ diterima $\left(\mathrm{H}_{\mathrm{a} 2}\right.$ ditolak); J ika $\beta_{2} \neq 0$ : $\mathrm{H}_{03}$ ditolak $\left(\mathrm{H}_{\mathrm{a3}}\right.$ diterima $) . \mathrm{H}_{03}$ diterima $\left(\mathrm{H}_{\mathrm{a} 3}\right.$ ditolak) artinya voluntary disclosure secara parsial tidak berpengaruh terhadap cost of capital, sedangkan $\mathrm{H}_{03}$ ditolak $\left(\mathrm{H}_{23}\right.$ diterima) artinya vol untary disclosure secara parsial berpengaruh terhadap cost of capital.

\section{HASIL DAN PEMBAHASAN}

\section{Hasil Pengujian Regresi Linear Berganda}

pengaruh masing-masing variabel independen terhadap variabel dependen secara rinci dapat dilihat pada Tabel 1.

\begin{tabular}{cccc}
\hline Model & \multicolumn{2}{c}{ Unstandardized Coefficients } & Standardized Coefficients \\
\hline & B & Standard Error & Beta \\
\hline ( Constant) & -.402 & .944 & \\
IA & -1.208 & .970 & -.126 \\
VD & .080 & 1.199 & .066 \\
\hline
\end{tabular}

Dari hasil perhitungan statistik seperti yang terlihat pada Tabel 1 maka diperoleh persamaan regresi linear berganda $Y=-0.402-1.208 X_{1}+0.808 X_{2}+\varepsilon$. Dari persamaan regresi tersebut dapat diketahui bahwa konstanta $(\alpha)$ sebesar 0,402 . Artinya jika informasi asimetri (IA) dan vol untary disclosure (VD) dianggap konstan, maka besarnya cost of capital (COC) adalah -40,2. Berdasarkan Tabel 1 didapatkan hasil bahwa $\beta_{\mathrm{i}} \neq 0$, dimana $\hat{a}_{1}=-1,208, \beta_{2}=0,808$, sehingga $\mathrm{H}_{\mathrm{a1}}$ diterima. Dengan demikian dapat dikatakan bahwa informasi asimetri dan voluntary disclosure secara bersama-sama berpengaruh terhadap cost of capital perusahaan.

Uji parsial dapat disimpulkan dengan melihat pengaruh masing-masing variabel independen terhadap variabel dependen yang terlihat dalam Tabel 1 , yaitu:

a. Pengaruh Informasi Asimetri terhadap Cost of Capital Perusahaan

Informasi asimetri (IA) dengan bid-ask-spread sebagai indikator mempunyai nilai koefisien regresi $-1,208\left(\beta_{1} \neq 0\right)$. Dalam rancangan pengujian hipotesis disebutkan bahwa jika $\beta_{1} \neq 0$ maka informasi asimetri berpengaruh terhadap cost of capital perusahaan, sehingga kesimpulan yang dapat diambil adalah 
menolak $\mathrm{H}_{02}$ dan menerima $\mathrm{H}_{\mathrm{a} 2}$. Hal ini berarti bahwa informasi asimetri berpengaruh negatif terhadap cost of capital perusahaan. Hasil penelitian ini sejalan dengan penelitian yang dilakukan Mardiyah (2002) yang menunjukkan informasi asimetri mempunyai pengaruh terhadap cost of capital perusahaan. Dalam penelitiannya informasi asimetri menunjukkan adanya hubungan secara negatif dengan cost of capital perusahaan. Yang berarti setiap penurunan informasi asimetri akan menurunkan cost of capital perusahaan, dan sebaliknya setiap peningkatan informasi asimetri akan meningkatkan cost of capital perusahaan. Hasil penelitian ini tidak konsisten dengan penelitian yang dilakukan oleh Murni (2004) yang menyatakan bahwa adanya pengaruh informasi asimetri terhadap cost of capital perusahaan. Dalam penelitiannya informasi asimetri menunjukkan adanya hubungan positif dengan cost of capital perusahaan.

b. Pengaruh Voluntary Disclosure terhadap Cost of Capital Perusahaan

Voluntary disclosure (VD) mempunyai nilai koefisien regresi $0,808\left(\beta_{2} \neq 0\right)$. Dalam rancangan pengujian hipotesis disebutkan bahwa jika $\beta_{2} \neq 0$ maka voluntary disclosure berpengaruh terhadap cost of capital perusahaan, sehingga kesimpulan yang diambil adalah menerima $\mathrm{H}_{\text {a3 }}$ dan menolak $\mathrm{H}_{03}$. $\mathrm{Hal}$ ini berarti bahwa vol untary discl osure berpengaruh terhadap cost of capital perusahaan.

Hasil penelitian ini sejalan dengan penelitian yang dilakukan oleh Gulo (2000), Mardiyah (2002), J uniarti dan Yunita (2003) dan Murni (2004) yang menunjukkan voluntary discl osure mempunyai pengaruh terhadap cost of capital perusahaan. Dalam penelitiannya vol untary discl osure menunjukkan adanya hubungan secara positif dengan cost of capital perusahaan.

Dari hasil tersebut dapat ditarik kesimpulan bahwa tingkat voluntary disclosure berpengaruh terhadap cost of capital, artinya semakin banyak perusahaan yang mengungkapkan mengenai jati diri dan identitas perusahaan maka akan semakin besar cost of capital yang dikeluarkan perusahaan. Sebaliknya semakin sedikit informasi yang diungkapkan maka akan semakin kecil cost of capital yang dikeluarkan perusahaan.

\section{SIMPULAN}

Berdasarkan pembahasan hasil penelitian yang telah dikemukakan sebel umnya, dapat disimpulkan bahwa:

1. I nformasi asimetri dan voluntary discl osure secara bersama-sama berpengaruh terhadap cost of capital pada perusahaan manufaktur yang terdaftar di Bursa Efek Indonesia.

2. Informasi asimetri secara individual berpengaruh terhadap cost of capital pada perusahaan manufaktur yang terdaftar di Bursa Efek Indonesia.

3. Voluntary disclosure secara individual berpengaruh terhadap cost of capital pada perusahaan manufaktur yang terdaftar di Bursa E fek Indonesia.

\section{DAFTAR PUSTAKA}

Almilia, Luciana Spica dan I kka Retrinasari. 2007. Analisis Pengaruh karakteristik Perusahaan Terhadap Kelengkapan Pengungkapan dalam Laporan Keuangan. Proceeding Seminar Nasional. J akarta: FE Universitas Trisakti, 9 J uni: 1-16.

Atmaja, Lukas Setia. 2008. Teori dan Praktek Manajemen Keuangan. J akarta: CV.ANDI. 
Pengaruh Informasi Asimetri...
Botosan, C.A. 1997. Disclosure Level and the Cost of Equity Capital. TheAccounting Review. Vol. 72 No. 3: 323-349.

Bramantyo. 2008. "Peluang Investasi dan Biaya Modal". Harian Umum Sinar Harapan. Artikel: 1-2.

Diamond, D., and R. Verreecchia. 1991. Disclosure, Liquidity and the cost of Equity Capital. The J ournal of Finance. Vol . 46 N o. 4: 1325-1359.

Djakman, Chaerul. 2000. Terjemahan Dasar-dasar Manajemen Keuangan. J akarta:Sal emba Empat.

Elliot, R.G. dan P.D. J acobson. 1994. Cost and Benefit of Business Information Disclosure. Accounting Horizon. Vol. 8 No. 4: 80-96.

Gulo, Yamotuho. 2000. Analisis Efek Luas Pengungkapan Sukarela dalam Laporan Tahunan terhadap Cost of Equity Capital Perusahaan. J urnal Bisnis dan Akuntansi. Vol. 35, No. 2: 138-150.

Halim dan Hidayat. 2000. Studi Empiris tentang Pengaruh Volume Perdagangan dan Return terhadap Bid-Ask-Spread Saham Industri Rokok di Bursa E fek J akarta dengan Model Koreksi Kesalahan. J urnal Riset Akuntansi Indonesia. Vol.3 No.1: 69-85.

Hertanti, Dewi. 2005. Pengaruh Faktor-Faktor Fundamental Terhadap Kelengkapan Pengungkapan Laporan Keuangan Perusahaan Manufaktur yang Terdaftar di Bursa Efek J akarta. Skripsi. Fakultas IImu Sosial Universitas Negeri Semarang.

J uniarti, Indira dan Yunita. 2003. Pengaruh Tingkat Disclosure terhadap Biaya Ekuitas. J urnal Akuntansi dan Keuangan. Vol. 17 No. 3:78-92. Universitas Kristen Petra

Khomsiyah dan Susanti. 2003. Pengungkapan, Asimetri Informasi dan Cost of Capital. Simposium Nasional Akuntansi VI Surabaya. 1008-1018.

Komalasari. 2000. Asimetri Informasi dan Cost of Equity Capital. Simposium Nasional Akuntansi III J akarta. 907-930

Mardiyah, Aida Ainul. 2002. Pengaruh I nformasi Asimetri dan Disclosure terhadap Cost of Capital. J urnal Ekonomi dan Bisnis Indonesia. Vol. 15 No. 2:70-82.

Mayangsari, Sekar. 2001. Manajemen Laba dan Motivasi Manajemen. Media Riset Akuntansi, Auditing dan Informasi, Vol. 1, No. 2: 88-102.

Murni, Siti Asiah. 2004. Pengaruh Luas Ungkapan Sukarela dan Asimetri I nformasi terhadap Cost of E quity Capital pada Perusahaan Publik di Indonesia. J urnal Riset Akuntansi Indonesia. Vol. 7, No. 2: 192-206. 